\title{
Revealing the impact of 17 mutations of human FMO3 protein associated with trimethylaminuria on its local spatial properties: a bioinformatic approach
}

\author{
TV Borodina*, SE Vakal \\ From International Conference for Healthcare and Medical Students (ICHAMS) 2013 \\ Dublin, Ireland. 11-12 October 2013
}

\section{Background}

Trimethylaminuria (TMAU) is a rare metabolic disorder manifesting in enormous excretion of trimethylamine (TMA) with urea, sweat and breath that leads to unpleasant body odour similar to rotting fish. TMAU has a strong genetic basis: 18 mutations (associated with 17 amino acid substitutions or chain truncation) of flavincontaining monooxygenase 3 (FMO3) are now recognized as a causative factor of TMAU. Surprisingly, only few of them are related with active site structure, while the molecular basis of other mutations impact on the protein structure is unknown. Moreover, there are no FMO3 models solved experimentally. So, the aim of study was to reveal the effects of 17 known mutations on human FMO3 structure by means of structural bioinformatics techniques.

\section{Methods}

Full-size modelling of normal FMO3 structure was performed with multiple template-based homology modelling and fragment threading techniques in MODELLER and FUGUE software. Point mutations were created with special MODELLER script and DeepView in parallel. Geometry optimization was performed with GROMOS96 force field. Binding sites were identified with Q-Site Finder and SURFNET. List of mutations were taken from Zhou and Shephard paper. Structural analysis of FMO3 normal and TMAU-associated structures was performed with UCSF Chimera. Aggregation \section{Ukraine

ESC, Institute of Biology, Taras Shevchenko National University of Kyiv,

\section{Conclusions}

1) Full-size structures of human normal and TMAUassociated FMO3 protein are obtained; 2) Most of TMAU-associated mutations possess local destabilizing effect on spatial structure; 3) NADP binding and aggregation tendency aren't usually affected; 4) Surfacestabilizing ligands for FMO3 are potential drugs for TMAU treatment (next steps). 
doi:10.1186/1753-6561-9-S1-A59

Cite this article as: Borodina and Vakal: Revealing the impact of 17

mutations of human $\mathrm{FMO} 3$ protein associated with trimethylaminuria

on its local spatial properties: a bioinformatic approach. BMC Proceedings 2015 9(Suppl 1):A59.

Submit your next manuscript to BioMed Central and take full advantage of:

- Convenient online submission

- Thorough peer review

- No space constraints or color figure charges

- Immediate publication on acceptance

- Inclusion in PubMed, CAS, Scopus and Google Scholar

- Research which is freely available for redistribution 